\title{
Domestic Violence Against Women in Rural Communities in Poland
}

\begin{abstract}
Domestic violence is a difficult topic to research and to write about. It is assumed that we know about only a small part of the violent behavior that occurs, because the victims of violence often decide to conceal the experience. From the statistics we have, we nevertheless know that the scale of the problem is serious. In addition, it seems to be a contentious ideological and political issue; in Poland there has been resistance by some groups to ratifying the Istanbul Convention. Experience in other countries and the idiosyncrasies of rural communities in Poland suggest that it might be even more difficult to analyze the problem of domestic violence in rural families. The very small number of studies and publications on this topic seems to prove the hypothesis. The goal of this article is first to present definitions of domestic violence, the scale of the problem, and the steps taken to prevent violence in rural areas in Western countries, and then to present research into violence in rural areas in Poland.
\end{abstract}

Key words: domestic violence, violence against women, rural women, diaries/journals of rural women.

\section{Introduction}

Domestic violence is studied in many different fields, including law, psychology, and sociology (see Levinson 1989; Counts, Brown, Campbell 1992; Heise 1998; Pospiszyl 2000; Herzerberg 2002; Mazur 2002; Buzawa, Buzawa 2003; Gruszczyńska 2007; Jackson 2007; Mellibruda 2012). It is addressed in empirical works, reports, and practical preventative programmes. ${ }^{1}$ The literature concerning domestic

The author is researcher of the Institute of Rural and Agricultural Development of the Polish Academy of Sciences (IRWIR PAN), ul. Nowy Świat 72, 00-330 Warszawa, e-mail: sibia@wp.pl.

1 See also Report, "Domestic Violence Against Women”, http://ec.europa.eu/public_opinion/archives/ebs/ebs_344_en.pdf [accessed: 12.08.2016]; http://statystyka.policja.pl/st/wybrane-statystyki/ przemoc-w-rodzinie/50863,Przemoc-w-rodzinie.html [accessed: 12.08.2016]; http://statystyka.policja. $\mathrm{pl} / \mathrm{st} /$ wybrane-statystyki/przemoc-w-rodzinie/50863,Przemoc-w-rodzinie.html [accessed: 12.08.2016]; https://msw.gov.pl/pl/aktualnosci/13576,Przemoc-w-rodzinie-badanie-MSW.html [accessed: 19.09.2015]; 
violence and violence against women in the developing countries is fairly extensive (Hartmann, Boyce 1983; Rao 1997; Jejeebhoy 1998, 2000; Wojtczak 2006; Rajska-Kulik 2007). It should be emphasized, however, that even though studies of violence often concern a representative sample (which includes the rural population), the place of residence is very rarely considered in analyzing and interpreting the results. That the situation of rural inhabitants affected by violence is exceptional has so far been reflected in only a few reports or articles (Brookbank 1995; Niczyporuk 2004; Wendt 2009a, 2009b, 2010; Wendt, Hornosty 2010; Owen, Carrington 2014; George, Harris 2015). ${ }^{2}$ These have most often involved research conducted in rural areas in Australia, Canada, or the USA. Therefore, we do not know much about the scale and idiosyncrasy of violence in the rural environment, and in particular we do not know about the problems faced by rural victims of violence. It is difficult to conduct research because victims, perpetrators and witnesses often prefer not to talk about the problem that affects them. In Poland we are also impeded by the fact that domestic violence has become politicized.

In this article the most common definitions of domestic violence are presented, including the specific nature of domestic violence in rural areas. On the basis of quantitative research, this article presents the scale of domestic violence in Poland and the factors that, in the opinion of the researchers, favour the incidence of such behaviour, with particular regard to the factors that concern people living in rural areas. The subsequent part of the article provides a view of rural domestic violence based on qualitative rather than quantitative data, based on the written reminiscences of rural woman.

\section{Definitions of domestic violence}

Domestic violence is a pattern of behavior which involves violence or other abuse by one person of another person in a domestic setting such as marriage or cohabitation; it can also involve violence against children in the family. In the European Union, "violence against women" is defined as "any act of gender-based violence that results in, or is likely to result in, physical, sexual or psychological harm or suffering to women, including threats of such acts, coercion or arbitrary

\footnotetext{
https://www.mpips.gov.pl/gfx/mpips/userfiles/_public/1_NOWA\%20STRONA/Przemoc\%20w\%20rodzinie/ dane\%20statystyczne/2\%20RAPORT_PRZEMOC_W_RODZINIE_IDEABLOG_FIN.pdf [accessed: 12.07.2016]; http://www.fundacjaster.org.pl/upload/Raport-STERu-do-netu.pdf [accessed: 12.08.2016]; http://nastawnia.com.pl/mocprzemocy/pliki/raport_mocwprzemoc.pdf [accessed: 12.08.2016];

2 See also Domestic Violence Awareness in Rural Communities (1999) http://www.vawnet.org/ assoc_files_vawnet/nrc_rural-full.pdf [accessed: 11.07.2016]; M. Northcott, Domestic Violence in Rural Canada' http://www.justice.gc.ca/eng/rp-pr/cj-jp/victim/rd4-rr4/p2.html [accessed: 11.07.2016].
} 
deprivation of liberty, whether occurring in public or in private life." 3 In Polish $\mathrm{law}^{4}$ domestic violence is defined as "a single or repeated willful act or omission which violates the rights or personal well-being of family members, ${ }^{5}$ in particular exposing those individuals to a risk of loss of life or health, violating their dignity or bodily integrity, or their freedom, including sexual freedom, injuring their physical or mental health, as well as producing suffering and moral harm in those individuals affected by violence."

Domestic violence can take a number of forms, including physical, verbal, emotional, economic, religious, and sexual abuse, which can range from subtle, coercive forms to marital rape or violent physical abuse such mutilation of female genitals, acid attacks causing disfigurement or death, or forced marriages. Domestic murders include stoning, bride burning, honour killings, and dowry deaths.

Statistics show that in most cases of domestic violence the person who experiences the violence is a woman and the majority of perpetrators are men (Cox 2015) and women tend to experience more severe forms of violence (McQuigg 2011, García-Moreno, Stöckl 2013). The most common form of violence against women is intimate partner violence and domestic violence caused by a current or previous partner (WHO 2010; Phillips, Vandenbroek 2014).

The definitions of violence experienced by women and their children can be specific, for example, the United Nations' definition says that violence against women is any act of gender-based violence that causes "physical or psychological harm or suffering to women, including threats of such acts, coercion or arbitrary deprivation of liberty" (United Unions 1993). This is the reason for research being conducted and programmes being implemented, which are dedicated especially to women.

\section{Domestic violence in rural areas - the scale of the problem}

There is very limited literature about the problem of domestic violence in rural areas and authors who try to write about this important issue often conclude that there is a lack of empirical data. Researchers emphasize that credible results of those kinds of studies are problematic and the likelihood is that the scale of the problem is greater than that appearing from the research. In Poland at least, the

3 'Domestic Violence Against Women Report', http://ec.europa.eu/public_opinion/archives/ebs/ ebs_344_en.pdf [accessed: 12.08.2016].

4 Article 2. 2 of the Act of 29 July 2005 on preventing domestic violence, amended in 2010.

5 The law defines a family member as "a closely related person as defined by Article $115 \$ 11$ of the Act of 6 June 1997 - Criminal Code (Journal of Laws, No. 88, item. 553, as amended), as well as a cohabitating person." 
rate of occurrence is most often illustrated by means of police statistics, ${ }^{6}$ without distinguishing between urban and rural areas. The incidents recorded in police statistics seem to be only the tip of the iceberg. Many victims do not report acts of violence, for both social and psychological reasons, such as shame, fear, lack of trust in the appropriate institutions, etc.

Difficulty in conducting research results from the fact that individuals who have been subjected to violence (as well as those who perpetrate it) are unwilling to talk about their experiences. The experience of violence is often denied by the victims, who do not want to recall traumatic events. Violence is often concealed by perpetrators, victims, and witnesses. Such behaviour can have a number of causes - shame, disinclination to interfere, fear of possible consequences. Violence, particularly domestic violence, is thus a complicated research subject on account of the sensitive subject matter, and the findings of the research are most likely quite imprecise.

In Poland, the data in various studies on domestic violence differs on case by case basis. According to the research from 2015 commissioned by the Ministry of Home Affairs, $14 \%$ of Poles declared that in the 2014 they had witnessed domestic violence, and only two in five respondents had decided to report it to appropriate institutions. $^{7}$

According to research by MillwardBrown, ${ }^{8} 44 \%$ of adult Poles admitted that they had at some time experienced violence from a member of their family $(38 \%-$ psychological violence, $27 \%$ - physical violence, and $5 \%$ - sexual violence). $32 \%$ confessed to having used violence against a family member at some time in their lives (26\% - psychological, $16 \%$ - physical, and $1 \%$ - sexual). In the opinion of the majority of Poles (59\%), from $20 \%$ to $59 \%$ of the Polish population is directly affected by domestic violence; $23 \%$ argue that domestic violence affects more than $60 \%$. Only $12 \%$ of the research sample claim that violence affects less than $19 \%$ of the population in Poland.

The most difficult research topic is sexual violence, because of its personal, intimate nature, the social taboo, and the psychological protection mechanisms of victims and aggressors. It is very difficult to estimate the scale of this type of violence, but it is one of the most important challenges facing current researchers of women's issues. This type of research needs skill, tools, preparation, and a special

6 http://statystyka.policja.pl/st/wybrane-statystyki/przemoc-w-rodzinie/50863,Przemoc-w-rodzinie. html [accessed: 12.08.2016].

7 https://msw.gov.pl/pl/aktualnosci/13576,Przemoc-w-rodzinie-badanie-MSW.html [accessed: 19.09.2015].

8 https://msw.gov.pl/pl/aktualnosci/13576,Przemoc-w-rodzinie-badanie-MSW.html [accessed: 19.09.2015]. 
methodology. An interdisciplinary approach would seem to be useful in a type of research where the experience and perspective of a minority group is important, and the researchers are focused on the subjective experiences of victims of violence.

In 2015, two research projects on sexual violence were conducted in Poland. ${ }^{9}$ The findings show that $87 \%$ of the female respondents had encountered some form of sexual abuse in their lives. $37 \%$ of the respondents had participated in sexual activity against their will, $23 \%$ had experienced attempted rape, and $22 \%$ had been raped. In the majority of cases, the perpetrator was someone well-known to the victim: a present $(22 \%)$ or former $(63 \%)$ partner, and the incident occurred in a flat (55\%). The said research reveals both the enormous scale of sexual violence against women and its "grey zone" - domestic violence that is not reported to law enforcement authorities, of which the victim's friends and family are unaware. ${ }^{10}$ It should also be added that the definition of sexual violence in that study was very broad. Unfortunately, in that survey as well, no analysis was conducted in regard to the respondents' place of residence (although rural inhabitants took part in the study).

\section{Domestic violence in rural communities - research, data, and conditions}

As it has been emphasized, violence - particularly domestic violence - is a difficult research subject and the results acquired from the surveys undertaken are probably not very precise. It would seem, however, that it is particularly difficult to acquire information concerning the scale and extent of the problem of domestic violence in the rural setting.

A number of risk factors have been determined in regard of the sources of domestic violence. Economical crisis, lower incomes, unemployment, instability, and the risk of homelessness are all factors that make it difficult for males to play traditional male social roles. In patriarchal communities, a man whose privileged status has been curtailed may attempt to regain power - sometimes with the use of violence. In patriarchal culture, aggression and violence are attributes of manhood (see Connell 1987). There are also factors such as financial stress or poverty. According to WHO, women from the world's poorest regions are most likely to experience violence (WHO 2013), but in rich countries as well violence is linked with poverty. Women share a fear of their partner's reaction if they leave; they may have economic concerns for themselves and their children, and societal and/or familial

9 http://www.fundacjaster.org.pl/upload/Raport-STERu-do-netu.pdf [accessed: 12.08.2016]; http:// nastawnia.com.pl/mocprzemocy/pliki/raport_mocwprzemoc.pdf [accessed: 12.08.2016].

10 'Przełamać tabu. Raport o przemocy seksualnej'. STER p. 8, http://www.fundacjaster.org.pl/upload/ Raport-STERu-do-netu.pdf [accessed: 12.08.2016]. 
pressure to stay in the relationship. ${ }^{11}$ Other factors that may expose women to violence include e.g. the fact that a victim has experienced abuse in childhood, pregnancy (which increase dependence of woman), separation from friends and family, dependence on the perpetrator, young age, and disabilities. Some authors mention alcohol and drug abuse, as substances leading to lowered inhibitions and weakened social norms.

Although there are many similarities in all women's and children's experiences of domestic violence, there are some factors that make domestic violence in rural families specific. It is important to be aware of this if we want to create programmes to deter violence. Such an awareness is also important in collecting data about the scale of violence in rural areas.

As specialists have emphasized, the unique characteristics, social structures, and lifestyles in non-urban communities must be remembered in order to understand the specific experience of domestic violence in rural communities (Niczyporuk 2004; Wendt 2009a, 2009b; Owen, Carrington 2014; George, Harris 2015; Wendt et al. 2015). Social norms and values, including the priority of group's well-being over that of the individual - i.e., the acceptance of sacrificing individual happiness for the sake of group interest - may lead victims to keep silent, to minimize the experience of domestic violence, and to refrain from asking for help and support. These common values can contribute to a lack of accountability for the perpetrators, the community's protection of aggressors, and the shaming of victims of domestic violence (Owen, Carrington 2014; George, Harris 2015).

Traditional gender norms are also still present more visibly in rural communities (George, Harris 2015; Wendt et al. 2015), where the model of masculinity is often connected with strength, domination, and courage (Carrington, Scott 2008). This social model is also present in the rural family model, which has a very traditional and patriarchal structure, with acceptance of male control, domination, and privileges. This model may contribute to acquiescence of male control and abuse; acts of violence might be justified by society as part of the dominant male's role in the family (Wendt 2009b; George, Harris 2015).

Another social characteristic of the rural lifestyle that could affect domestic violence is the opinion that families should solve their problems in privacy, and individuals should be strong, patient, and self-reliant (Niczyporuk 2004; Wendt 2009b; Carrington et al. 2013; Owen, Carrington 2014). These norms contribute to the issue of domestic violence being ignored and minimized. Women are deterred

11 M. Campo, S. Tayton, 'Domestic and family violence in regional, rural and remote communities', https://aifs.gov.au/cfca/sites/default/files/publication-documents/cfca-resource-dv-regional.pdf [accessed: 12.08.2016]. 
from seeking help and from leaving the relationship. Looking for help in institutions and support centers can be perceived by family or society as a betrayal, resulting in shame and a kind of stigmatization and social exclusion (Wendt 2009a, 2009b; Ragusa 2013; Owen, Carrington 2014). These social influences are related with a lack of privacy, which is also characteristic of small communities and rural areas. Strong social control could work to restrain potential perpetrators, but not when the value system recognizes violence and male domination. For a victim it may be very difficult to take steps to change an abusive situation, because abusive behaviours may be seen as normal.

The invisibility of domestic violence results in impunity of aggressors, who are not held accountable for their actions. Research in Australia shows that a community may act to protect perpetrators, especially if they are of high standing or play important roles in the community (Owen, Carrington 2014; George, Harris 2015).

Financial dependence is another reason why women may have difficulty ending an abusive relationship - and not only in rural areas. Without money, women cannot find a new place to live, and have no access to transportation, food, clothing, etc. But in farming communities, the situation could be even more difficult: money is often invested in land, heavy equipment, or other assets that are difficult to sell and are managed and controlled by husbands, fathers, or brothers. Women often have no access to their own sources of income (Owen, Carrington 2014).

There are also some strictly spatial, geographical aspects that distinguish domestic violence in rural areas. Women from rural areas who experience domestic violence may be geographically and socially isolated, which can make perpetrators feel that they are beyond the law; they can make use of this fact to limit or control access to transportation, phones, etc. Geographical distance can also result in social isolation from friends, family, services, jobs, and institutions or NGOs that could help victims of violence.

In Poland, in rural communities violence has also to a certain degree been considered an acceptable behaviour and treated as a natural element of daily life. As Niczyporuk (2004) observes, every culture sanctions the use of violence to some degree and in certain circumstances. She also emphasizes that the countryside is a place in which a number of factors come together with the result that the disclosure and resolution of domestic conflict can be particularly difficult. Rural hierarchy is a factor that can hamper preventative measures, with the subordination of the individual and private sphere to group interests such as those of the family or even the entire rural community. Violence has always been a common method of punishing insubordination and as such, has been socially accepted and sanctioned. Among other reasons, there are very few organizations in the countryside that are engaged in combating violence and aiding its victims, and the statistical data 
in Poland does not usually include information about the environment in which the act of violence occurs. In the "Diagnosis of Individuals Engaging in Domestic Violence," 12 the experts who were interviewed stressed that rural inhabitants experience violence more often than urban inhabitants but that there were more preventative activities and programmes in urban environments. This could result from the fact that the institutions engaged in preventative actions and aid are predominantly located in cities; it is more difficult for rural inhabitants to obtain help and support when they experience violence. There are many other reasons for the difficulty in uncovering domestic violence, including confidence levels and social controls, social consciousness, the accessibility and quality of institutional schemes intended to render assistance, etc.

\section{The biographical method and the memoirs of rural women}

As it has been mentioned, one problem of researchers studying violence is the lack of data and the difficulty in collecting it, which is particularly visible in reference to data from rural communities. On account of the lack of empirical data concerning domestic violence in the countryside, it was decided for the needs of this article to make use of memoirs, which are often used in sociological works. Memoirs are personal and conscious documents about the lives of individuals, which express their subjective convictions while locating them in the historical and socio-cultural context. As Znaniecki observed (Znaniecki 1938, p. XI), for sociology, memoirs are not only a category of individual experiences, they are documents that reveal the supra-individual social world. Biographical data provides a special kind of information. While investigating sequences of events that are typical of a given group it should be kept in mind that issues connected with the maturity of the people under consideration, the people's memories, their desire to present themselves positively, and the literary form on which they have decided (for instance, a sad story or a cheerful story), could distort the reality being described. It is possible to check sources (documents, interviews, etc.) by triangulation, that is, by cross-examination, and by analysis from the perspective of the various actors in a relationship with the person studied. The procedure of 'establishing the facts' consists therefore in seeking agreement between the various sources and perspectives. However, what counts as "facts" in the research group must often be reconstructed by the sociologist. Currently, personal documents, i.e., biographical

12 https://www.mpips.gov.pl/gfx/mpips/userfiles/_public/1_NOWA\%20STRONA/Przemoc\%20w\%20 rodzinie/dane\%20statystyczne/1\%20RAPORT_POLACY_PRZEMOC_W_RODZINIE_FIN.pdf [accessed: 20.09.2015]. 
documents, are most often recognized to be "acts of social consciousness". The biographical method is characteristic of Polish sociology of the countryside, and has been employed by such outstanding scholars as Florian Znaniecki, Józef Chałasiński, Ludwik Krzywicki, and Władysław Grabski (Pawłowska 2009, p. 63).

This method is special for the sources the researcher uses. Znaniecki called attention to the fact that information the sociologist wants to make the object of analysis exists and has significance only when it constitutes the object of the reflection and activities of representatives of the specific human community that interests the researcher (Znaniecki 1934). In applying this method, the researcher is striving not only to draw up an exact record of facts but also to verify hypotheses and formulate the most precise generalizations possible; in order to resolve the questions posed and describe the object of study, people's reminiscences about their participation in the events and processes constituting that object are collected. Chałasiński (1984) considered that autobiographical material provides a description of the author's social situation, with the author's attitude and actions in that situation. What the author of an autobiography writes is important to a sociologist not as a description of objective facts, but as an expression of the writer's aspirations and social attitudes. Studying the individual provides information about the group to which that individual belongs - its values, culture, structure, norms, etc.

There are various methods of interpreting and using personal documents (including, most frequently, the constructive method, the exemplification method, the textual analysis method, statistical work on material collected from memoirs, and typological analysis) (cf. Szczepański 1971). This approach could be useful both in verifying certain hypotheses and in formulating new questions and the aims of future research. In the analysis below the exemplification method and textual analysis method will chiefly be employed, although undoubtedly the existing material could be used in a broader manner, and could be the basis for further work in the future. On account of the time in which the source material emerged, the present analyses will concern perception of the phenomenon of domestic violence in rural communities in the past.

We find the stories of rural women who have experienced violence (physical, psychological, or economic) in documents collected and preserved thanks to competitions organized in Poland for the diaries and memoirs of rural inhabitants. Both before and after the Second World War, a comparatively large number of such competitions were organized, and sometimes they were intended specifically for women. No competition was directly concerned with the experience of violence. Such reminiscences appear in memoirs rarely, and when they do they are on the margins of descriptions of other events, even though the recorded incidents are often quite drastic. 
The stories of experiences of violence (both in the family of origin and in marriage) that are analyzed in this text come from two sources. The first was a memoir contest for rural women held in 1970 by the Institute for Research into Industrial Regions. Selected texts ${ }^{13}$ were published in three volumes of collected reminiscences (Jagiełło-Łysiowa 1975; Tryfan 1975; Jakubczak 1976). The second source is the collection of texts selected from among nearly 1,500 memoirs submitted to the "To Be a Mother" memoir-writers' contest (Gałaj 1985). The age of the authors varied from 35 to 83 , and the periods described by them covered nearly one hundred years of Polish women's experience. Unfortunately, in spite of searching, it was not possible to find the complete sets of materials that were submitted to the contests (most probably they were destroyed); the basis of the analysis is thus the memoirs selected by the organizers for publication.

\section{Violence in the countryside in the memoirs of rural women}

The subject of domestic violence does not often appear in the memoirs of rural women; it is not the leading subject of the reminiscences, in this analyses we use 7 memoirs, in which domestic violence was mentioned by authors. Violence in the description of daily life appears on the margin of other events, often as if it were a normal element of everyday life. There are not many reminiscences in which the authors complain, or describe their situation as exceptional. They perceive their difficult situation, but treat it as something natural. This could result from a different - though broad - framework of the competition, whose aim was to capture rural life in full, or it could also be a consequence of the fact that in rural communities violence was to a certain degree an acceptable behaviour, treated as a natural element of daily life.

Violence within the family circle continued (and continues?) to be treated as private, personal, and often a matter of shame for the victim, as it could signify that she had not fulfilled her duties, had not behaved in accordance with social expectations, and for this reason had been subjected to punishment. This type of reaction to violence can be observed both in members of a family in which acts of violence occur, and in the social environment - the neighbours, more distant relatives, representatives of the authorities or the Church. In the passages below, it can be seen that the use of force was an ordinary and natural behaviour. Acts of violence were once a manner of resolving disputes or conflicts, and furthermore, as appears in the reminiscences, women - who are more often perceived as

131,200 works were submitted to the contest. 
victims - also had recource to violence. Violence was ingrained in the daily functioning of the inhabitants of the countryside.

Mama didn't want to let me go out without my sister. I had to humour my sister all day so she would go with me to the dance. If she went, she never wanted to stay to the end. When I returned home early with my sister, I would quarrel with her, and sometimes it even came to a fight. We pulled each others braids. I was quicker and roughed her up worse.

Memoir no. 1143, in Czyste wody moich uczuć [The Clear Water of My Emotions], ed. B. Tryfan, p. 75.

The work didn't go well for me, because I was continually worried by the knowledge that I had to convert my husband. I ordered him to pray, but he laughed at that. I resorted to blows, but I got such a beating that I gave up missionary work.

Memoir no. 105, in The Clear Water of My Emotions, ed. B. Tryfan, p. 57.

In the situations described it could be considered that the use of force occurs within the framework of an accepted - willingly or not - social contract, in which informal norms designate an individual's place in the group, require observance of the prevailing principles, and insubordination is punished, also physically. The problem appears, however, when the victim does not accept the order that sanctions the use of force; when such a person is punished for breaking a rule to which she did not agree, or about which she was not informed.

The principle of not interfering in the affairs of a married couple, as, e.g., how they relate to one another or how they raise their children, means that there is a lack of reaction even in situations where one is required: in families with problems such as alcohol abuse, in such situations the lack of reaction from the social environment and the lack of support produce real difficulties, and the victim is left to her own devices. The reminiscences quoted make the reader realize that the countryside lacks institutions, mechanisms, or even individuals who could help and support a person experiencing violence, the lack of a support system (formal or informal) for victims is also a serious problem in contemporary rural society in Poland.

It is possible that acceptance of violent behaviour continues in rural communities not only because of family pressure and fear of public opinion but also because of a strong position of the Catholic Church and its enduring propagation of "carrying one's cross" belief and promotion of marriage as the unbreakable bond. Violence is often treated as something inevitable, unalterable, and permanent in the situation of a specific individual. From the examples given below it can be concluded that the individuals from whom the victims might hope for a reaction were family members or possibly a spouse (unless he was the perpetrator of the violence). Here 
too, it is possible to perceive a certain acceptance of the fact that violence occurs; it is regrettable, but no attempts are made to change the situation or to curtail it.

After that, my stepmother began to have a baby every year. I had additional work then - taking care of her children. I remember perfectly how she made father into her tool - and if my work didn't please her she complained to my father and I received a beating for no reason [...] Once I picked weeds for the pigs and brought them to the yard. "What kind of weeds did you pick, you dumb shit!" she shouted, "Eat that yourself." So saying she shoved it into my mouth and kicked me until I fell. My father came but he did not react. [...]

I felt bitter and wanted to run away and go into service somewhere, but when my father found out he said, "If you go to work for someone else, I'll burn the place down that takes you in, and then I'll kill you!"

Memoir no. 105, in The Clear Water of My Emotions, ed. B. Tryfan, pp. 54 and 55 .

Fairly often in the reminiscences of rural women descriptions can be found of behaviour that would seem to fall within the category of economic violence. The situation of young couples, particularly those in an uncertain legal situation, without a notarized deed of conveyance of land or a farm, could be very difficult. It could happen that families took ruthless advantage of the power such a potential donation gave them to exploit their relatives, abusing them or requiring them to work beyond their strength without fear of possible rebellion. A woman who lived with her parents-in-law was in a particularly difficult situation, as she was not protected even by ties of blood. Most often women moved into their parents-in-law's house after marriage and could not count on help and support from them. However, as one of the passages below shows, a victim could experience such treatment even from her closest kin (in this case, her mother). Another type of economic violence is the disposal of assets without the knowledge or agreement of the spouse, against the spouse's will, as happens in some of the examples below. The instances of neglect, denial of food, and hampering access to basic necessities would seem to fit the definition of abuse, even if there is no direct application of force against the victim.

After ten days my husband returned and said, "we're leaving”. He informed my parents about our plans. The house became a living hell; perhaps Papa was quietly pleased; he knew his son wouldn't study any more, but Mama went crazy. Finally she asked me not to listen to stupid advice and to stay at home, because if I wanted to leave, then she wouldn't even give me that shirt, which I made myself. I was expecting; I didn't like fights; I begged Mama to allow me, for once in my life, to decide for good or ill about my own life. I was 
also very afraid of the trip to my husband's family. On the day of departure, Mama locked up all my things. I told her that she wouldn't keep anyone by her side that way.

Memoir no. 890, in Być matka [To Be a Mother], ed. D. Gałaj, p. 320.

He carted off and drank up everything he could, whatever he could find a buyer for, from little things to quite large, like selling land.

Memoir no. 804, in The Clear Water of My Emotions, ed. B. Tryfan, p. 108

I lay in bed for the first three days after a difficult birth, alone like a dog. My husband, busy with work, trusted that as his family was in the house I would be cared for. I didn't complain that they forgot about me, although we were divided by only a door. My husband went to his mother; he ate his meals there, and as he was the only son, he always got something better. I thought to myself that she was a simple country woman; she didn't even know how to write; I had to forgive her. [...] I gave birth to two more children in those same conditions. They were all seven-months' babies. None of the three lived. A body exhausted by work, and bad treatment, contributed to their deaths. My husband was afraid to stand up for me, because nothing had been conveyed to him by a deed yet, as promised. And if his parents got angry, they could change their minds and not give him anything. When I asked him why they treated me so inhumanly, he answered, "Don't say anything, because Father won't give us anything."

Thus I concealed my suffering - I even cried in hiding. [...]

I gave birth two weeks early; I was as cold and hungry as ever. The tears poured down my face. On the second day I dragged myself from the bed in order to bathe the child, who kept living this time. Thus, I had someone to live for. It was probably a miracle that I carried the child, because I was just a shadow. I asked my husband to bring me even something small to eat, because I had no strength left. He went out and said to his mother, "She wants to eat, she's hungry". I heard those words through the open door. Without a reply, he brought me a plate of the weak soup my mother-in-law cooked for the hired labourers; it had no vegetables and hardly any lard.

Memoir 804, in The Clear Water of My Emotions, ed. B. Tryfan, pp. 104-106.

After the money was gone, he took apart the well, so I wouldn't have water. The nearest was in my parents-in-law's yard. I was forced to go there to get water. They grudged me even water; they hid the scoop. I made myself one with a long pole; I hammered in a nail, and went in fear. The next day I saw that they had put a lock on it. I had to go a long way to get water, about a quarter of a kilometer. It gave pleasure to the family to cause me pain. Memoir no. 804 in The Clear Water of My Emotions, ed. B. Tryfan, p. 113.

Like a slave deprived of all rights, I was only for work. Even what I got for my painstaking work, like the napkins I embroidered in the evening for a rich neighbour, my husband took secretly and squandered. And it was intended 
for some sort of modest life for my children. I couldn't even keep those small sums I had stitched for myself by the light of the kerosene lamp. I had a dozen or so hens and turkeys; we lived humbly, from day to day. And I had to keep an eye out, because not only my husband but also my parents-in-law, even though they weren't in need of anything, would take eggs. And from time to time I found out that they had sold my hens, my only source of maintenance. Even if I knew, or caught them at it, what was I to do? I couldn't go to the police, because I didn't have anything to wear, I couldn't go barefoot, everyone knew us once, I came from a well-to-do home, we were very respected. I didn't want to show myself to people in that shape. I wasn't accustomed to humiliation. I preferred to die a hungry death than beg for mercy.

Memoir no. 804 in The Clear Water of My Emotions, ed. B. Tryfan, p. 109.

After severe torments, I gave birth to my first son. My husband did not bring me anything. I lay in bed helplessly for several days and then my strength began slowly to return. On the eighth day my husband took me home. I did not have strength to go into the yard. I had to hold onto something so as not to fall. For the first few days my husband heated water and placed the bath on the bed so I could bathe the child and wash the rags. He carried the water out. But that was only a few times. Later he told me that a mare rests three days and then goes back in harness, so you too have to do everything in the house (...) Memoir no. 827, To Be a Mother, ed. D. Gałaj, p. 465.

To a later date than in the cities, marriages in the countryside were arranged between families, not individuals; they were based on relations of obedience, group solidarity, and respect. Violence was accepted when there was a suspicion that a woman had transgressed these principles, and public opinion in rural society was against interfering in matrimonial matters. In the introduction to the collection of memoirs To Be a Mother, Gałaj describes a symptomatic, seemingly trivial, event which occurred in a village in central Poland in the interwar years, and which showed how a man's traditional role was viewed in the countryside and how much aggressive behaviour it encompassed. It also shows how much social acceptance there was for such behaviour.

The wedding procession returned from the church. The young couple came into a room in the bride's home and the first act of the groom was to hit his wife a few times - not particularly hard. The wedding guests looked on without being particularly moved and admonished the groom, saying, "Władek, why are you beating her? She hasn't done anything." Władek in answer to that said, 'I'm beating her so she's knows who's the master here. ${ }^{14}$ Introduction, To Be a Mother, ed. D. Gałaj, p. 96.

14 D. Gałaj (ed.) Być matką, Ludowa Spółdzielnia Wydawnicza, 1986, p. 96. 
As Gałaj observes, rural marriages lasted even when the wife was treated inhumanly - which in peasant conditions meant that she was beaten, sometimes severely. Gałaj stresses that in the past such behaviour was the norm, which no one protested or resented, if it occurred in moderate form. Milkiewiczowa, who undertook to analyze the peasant memoirs published by the Institute of Social Economics in 1935, concluded from reading them that "The husband's brutality and a woman's own religiosity make her subservient. She submits to her husband's will, convinced that in this manner she is fulfilling the divine will, and later she carries the child in her womb as if she were carrying the cross." (Milkiewiczowa 1999, p. 345).

[...] he became rather nervous, excitable. I told myself that he was ill and time passed somehow. But he began to shout insults at the children, and me he took to beating. Somehow spring came.

[...] I didn't pay attention to that, but after a time there was again a fight in the house. He jumped at me with an ax. I saw that it was no joke.

Memoir no. 114 in The Clear Water of My Emotions, ed. B. Tryfan, pp. 157 and 159.

[...] When I pleaded with him in protest, asking him what he was doing, asking him to think, because when he came to, it would be too late, I got a fist in the face, or whatever was at hand on the head. That was the answer to my pleas.

Memoir no. 804 in The Clear Water of My Emotions, ed. B. Tryfan, pp. 108-109.

Alcohol is a frequent motif accompanying domestic violence and undoubtedly contributes to increasing aggressive behaviour. Perhaps it is also easier for memoir writers to write about the question of violence when it is not connected with the character traits of their life partners but can be attributed to an "external" factor, that is, when a spouse's unacceptable behaviour can be blamed on alcohol. It also happens that a partner's tendency to violence is blamed on his susceptibility to the influence of other people, most often members of his family.

My husband's family gave me no rest. They began to try to instigate my husband to get rid of me, as I heard myself. He was afraid to kill me; he was too cowardly. But he more and more frequently drank and started fights. No one prevented him from tormenting us, and he even drove us from our beds into the snow at his parents' orders. All my husband's siblings looked on and no one said 'Enough!' They didn't even have pity on those little children! The children suffered terribly after all. His family only joked that it was like at the movies. Yes, like in the movies, but not for us, the ones who were maltreated. Memoir no. 804 in The Clear Water of My Emotions, ed. B. Tryfan, p. 107. 
I take on three and a half hectares of land. I work as best I know how; my children and parents help me. My husband won't turn to farming. He comes home late increasingly often. Neither pleas nor threats are of any use; he can't live without vodka. The house becomes a living hell. After drinking he breaks whatever comes to hand, while I argue, and beg, and cry. He's good when he's sober, but when he drinks - it's the same again. Sometimes the children and I spend the night in a haystack or the pigsty. I don't say anything to anyone, though. I already have grown children. I don't want anyone to know what happens in our house.

[...] my youngest daughter is living in bad conditions. I decide to take her in. I know what awaits me. Again there are fights in the house, again there are sleepless nights, but what won't a mother do for her children? My daughter is braver than I am, though; she won't let him hit her; she won't let him drink up all the money.

Memoir no. 665 in To Be a Mother, ed. D. Gałaj, pp. 190 and 191.

In the women's descriptions of their experience of violence, what is striking is the total lack of institutions or people who could help the person in need. In the collection of memoirs no mention is made of outside assistance - either from neighbours, who keep their distance from family matters, or from the Church, schools, or local authorities. There is no custom of intervening to defend the victims of domestic violence. If an expectation of help appears in the reminiscences, it is in regard to the victim's own family (often in the form of regret and resentment that help and support were not received), or the victim's husband, if he is not the perpetrator. The real manifestations of support described in the reminiscences come primarily from grown-up children (who do not plan to stay on their father's farm).

At that moment I saw my daughter hanging on his neck, begging her father not to destroy things, not to waste things. But he threw her from him, and without thinking hit her hand with a stake for fruit saplings. My daughter turned pale; her hand bent in an arc; I fainted. All my husband's sisters and his parents watched that scene. They were glad to see it. Memoir no. 804 in The Clear Water of My Emotions, ed. B. Tryfan, p. 112.

He jumped on me - he wasn't entirely sober - caught me by the throat, hit me in the head and wouldn't let go. The children tried to pull him off. They couldn't. Without stopping to think, my daughter grabbed a poker and supposedly hit him in the back. He let go, and saw that he was outnumbered, because my sons already had something in their hands too. I grabbed the stick for stirring the wash. He didn't know what to do.

Memoir no. 114 in The Clear Water of My Emotions, ed. B. Tryfan, p. 163. 
My eldest daughter is 17; she stands up for me. She won't let him beat me; she jerks the chair out of his hand, knocks him to the ground, and says, "If you ever raise a hand against Mama again, we'll all beat you." Since then, my husband drank, but he didn't start fights.

Memoir no. 665 in To Be a Mother, ed. D. Gałaj, p. 190.

\section{Conclusions}

The analysis of the phenomenon of domestic violence is difficult for several reasons, including the number of definitions of domestic violence, cultural differences, and methodological problems. Research often concentrates on what is easily accessible: social attitudes, sources of knowledge about violence, etc. It is harder to study the people directly affected by violence, as perpetrators, victims, and witnesses are often unwilling to talk about it. Even less is known about violence in rural communities, although research in many countries with more highly developed research methodologies has shown that it is a special phenomenon in many respects. In the opinion of specialists, the situation of rural inhabitants is distinct because rural society, characterized by a particular social structure and greater conservatism, has a stronger tendency to subordinate individual to group interests and resorts to violence when community norms are transgressed. This is emphasized by researchers from Australia, Canada, and the United States, as well as by specialists in Poland who are engaged in helping victims of domestic violence.

However, as very little empirical research has been done on rural domestic violence, I have used historical sources for the purpose of studying rural attitudes to the subject. On account of the long time period covered in the various memoirs this can be considered a historical analysis; undoubtedly it would be worthwhile to supplement it by contemporary research.

In the collection of memoirs that I have analyzed, I have discovered several recurring themes in the descriptions of violence in rural families. One is the universality of violence in relations between family members. It is interesting that while force and violence are attributed to the traditional male role, in the women's reminiscences we also find proof that violence was an accepted and 'normal' behaviour for women as well: if a woman could make use of it to her own ends, she used it, for instance, against a weaker sister, a child, or a drunken husband, who did not have the strength to defend himself.

The shame and the feeling of humiliation experienced by the victims of violence means that not only do they not seek external help and support, but they avoid writing about it, even in a form as personal as a memoir. Perhaps the knowledge that the text was meant for a contest and would be read by many people was 
another factor discouraging the author from revealing this type of experience. However, when acts of violence appear in the descriptions, they are often quite acute. They involve both physical violence and the psychological and economic violence perpetrated not only by a spouse or spouse's family but also by a person's own family and siblings. The unusual isolation of the victims is striking; in rural conditions they had no one to turn to for help. Marriage, which was entered into for family rather individual interests, was not intended to make the two spouses happy but to further the increase of common assets. It was a kind of a business transaction, whose success required the individual to relinquish his or her own desires, aspirations, or preferences. Rural society defended this order and unwillingly became engaged in family affairs. The countryside did not have institutions that were obligated to care for the victims of violence. In the memoirs, the only instances of help and support for the victims come from grown up or nearly grown up children, who help to curb the aggression and violence. Often they themselves are victims, which perhaps influenced their decision to take action.

The victims were often prevented from seeking help by shame and pride - the unwillingness to admit publicly that they had not succeeded at something. In analyzing the transformation of rural society in Poland, it is very important to ask whether rural society has changed so much that this kind of problem has become history. Unfortunately, due to hardly any research devoted to the phenomenon of violence, particularly in the countryside, suggests that it continues to be a taboo subject rather than that it does not exist. Violence is not talked about or written about or reacted to. Attempts to admit openly that the problem exists - as in the case of endeavors to improve the existing laws to protect the victims of domestic violence - produce furious protests of some politicians and groups. I hope that the above article, describing the experiences of the inhabitants of Polish villages, whose biographies cover nearly one hundred years of historical, political, and social change in Poland, will start discussions about violence in contemporary rural areas and will contribute to research highlighting this issue and describing it not from the historical but the contemporary perspective.

\section{Bibliography}

Brookbank C. (1995). Spouse Abuse in Rural Communities: A Review of the Literature. Ottawa: Department of Justice Canada.

Buzawa E., Buzawa C.G. (2003). Domestic Violence: The Criminal Justice Response. Thousand Oaks, California: Sage.

Caesar P.L. (1988). Exposure to violence in the families-of-origin among wife-abusers and maritally nonviolent men. Violence and Victims, 3, 49-63. 
Campo M., Tayton S., Domestic and Family Violence in Regional, Rural and Remote Communities; https://aifs.gov.au/cfca/sites/default/files/publication-documents/cfca-resource-dv-regional.pdf [accessed: 12.08.2016].

Carrington K., Scott J. (2008). Masculinity, Rurality and Violence. The British Journal of Criminology, 48 (5), 641-666.

Chałasiński J. (1984). Młode pokolenie chłopów: procesy i zagadnienia kształtowania się warstwy chłopskiej w Polsce. Vol. 1-4. Warsaw: Ludowa Spółdzielnia Wydawnicza.

Connell R.W. (1987). Gender and Power: Society, the Person and Sexual Politics. Stanford: Stanford University Press.

Counts D.A., Brown J.K., Campbell J.C. (1992). Sanctions and Sanctuary: Cultural Perspectives on the Beating of Wives. Boulder: Westview Press.

Cox P. (2015). Violence Against Women: Additional Analysis of the Australian Bureau of Statistics Personal Safety Survey. Sidney: Australia's National Research Organization for Women's Safety.

Dymarczyk W. (2012). Metoda dokumentów osobistych. In: K. Konecki, P. Chomczyński (ed.), Słownik socjologii jakościowej (pp. 173-176). Warsaw: Difin.

Gałaj D. (1986). Być matką. Warsaw: Ludowa Spółdzielnia Wydawnicza.

García-Moreno C., Stöckl H. (2013). Protection of sexual and reproductive health rights: Addressing violence against women. In: M.A. Grodin, D. Tarantola, G.J. Annas et al., Health and Human Rights in a Changing World (pp. 780-781). New York: Routledge.

George A., Harris B. (2015). Landscapes of Violence: Women Surviving Family Violence in Regional and Rural Victoria. Geelon: Centre for Rural and Regional Law and Justice, Deakin University.

Grabski W. (2004). Pamiętniki chłopów i środowisko społeczne wsi polskiej. In: W. Grabski, Prace socjologiczne (pp. 348-383), Warsaw: SGGW.

Gruszczyńska B. (2007). Przemoc wobec kobiet. Aspekty prawnokryminologiczne. Warsaw: Oficyna and Wolters Kluwer.

Hartmann B., Boyce J.C. (1983). A Quiet Violence: View From a Bangladesh Village. London: Zed Press.

Heise L. (1998). Violence against women: An integrated, ecological framework. Violence Against Women, 4, 262-290.

Herzberger S. (2002). Przemoc domowa. Perspektywa psychologii społecznej. Warsaw: Państwowa Agencja Rozwiązywania Problemów Alkoholowych.

Hornosty J., Doherty D. (2002). Responding to Wife Abuse in Farm and Rural Communities. Regina: Saskatchewan Institute of Public Policy.

Jackson N.A. (2007). Encyclopedia of Domestic Violence. New York: Routledge.

Jagiełło-Łysiowa E. (ed.) (1975). Rola przeorana, dom piękny. Warsaw: Książka i Wiedza.

Jakubczak F. (1968). Metoda pamiętnikarstwa masowego w badaniach nad współczesnością. In: Badania socjologiczne na Ziemiach Zachodnich (pp. 44-45). Materiały z konferencji w Poznaniu w dniach 1 i 2 marca 1968 r. Poznań: Instytut Zachodni.

Jakubczak F. (1963). O dokumentach pamiętnikarskich jako materiale źródłowym dla socjologii. Przegląd Socjologiczny, 2, 68-90. 
Jakubczak F. (1972). Metodologiczne problemy użytkowania dokumentów pamiętnikarskich w badaniach nad kulturą współczesną. In: K. Krzemień (ed.), Ruch pamiętnikarski i przemiany polskiej kultury (pp. 84-108). Warsaw: PWN.

Jakubczak F. (ed.) (1976). Być w centrum życia. Warsaw: Książka i Wiedza.

Jejeebhoy S.J. (1998). Wife-beating in rural India: A husband's right? Evidence from survey data. Economic and Political Weekly, 33, 855-862.

Jejeebhoy S.J. (2000). Women's autonomy in rural India: Its dimensions, determinants, and the influence of context. In: H.B. Presser, G. Sen (eds), Women's Empowerment and Demographic Processes (pp. 204-238). Oxford, England: Oxford University Press.

Jiwani Y., Moore S., Kachuk P. (1998). Rural Women and Violence: A Study of Two Communities in British Columbia. Vancouver: The FREDA Centre for Research on Violence against Women and Children, Simon Fraser University. http://www.harbour.sfu.ca/ freda/articles/rural01.htm [accessed 4.02.2010].

Kasdorff D., Erb B. (2010). Serving Victims of Violence in Rural Communities: Challenges and Best Practices. Ontario: Victim/Witness Assistance Program, East Region.

Knapik W. (2008). Kobieta w wiejskiej społeczności lokalnej. Toruń: Wydawnictwo Adam Marszałek.

Kotlarska-Michalska A. (2011). Społeczne role kobiet. Edukacja Humanistyczna, 1 (24), 25-35.

Levinson D. (1989). Family Violence in Cross-Cultural Perspectives. Newbury Park, CA: Sage.

Mazur J. (2002). Przemoc w rodzinie: teoria i rzeczywistość. Warsaw: Wydawnictwo Akademickie Żak.

McQuigg R.J.A. (2011). Potential problems for the effectiveness of international human rights law as regards domestic violence. In: R.J.A. McQuigg, International Human Rights Law and Domestic Violence: The Effectiveness of International Human Rights Law (p. 13). Oxford, New York: Taylor \& Francis.

Mellibruda J. (2012). Przeciwdziałanie przemocy domowej. Warsaw: Instytut Psychologii Zdrowia.

Milkiewiczowa M. (1999). Wieś polska ginie. In: C. Miłosz, Wyprawa w Dwudziestolecie (pp. 350-351). Cracow: Wydawnictwo Literackie.

Miłosz C. (1999). Wyprawa w Dwudziestolecie. Cracow: Wydawnictwo Literackie.

Niczyporuk D. (2004). Przemoc w kulturze wsi. Niebieska Linia, 5. http://www.niebieskalinia.pl/pismo/153-czasopismo/artykuly-nl?start=234 [accessed: 12.08.2016].

Owen S., Carrington K. (2014). Domestic violence service provision and the architecture of rural life: An Australian case study. Journal of Rural Studies, 39, 229-238.

Pawłowska K. (2009). Metoda pamiętnikarska w polskiej socjologii wsi - ujęcie antropologiczne. Wieś i Rolnictwo, 1 (142), 62-84.

Phillips J., Vandenbroek P. (2014). Domestic and Family Violence in Australia: An Overview of the Issues. Parliamentary Library Research Paper, Canberra: Parliament of Australia. http://www.aph.gov.au/About_Parliament/Parliamentary_Departments/Parliamentary_ Library/pubs/rp/rp1415/Quick_Guides/DVinAust [accessed: 12.08.2016].

Pospiszyl I. (2000). Przemoc w rodzinie. Cracow: Wydawnictwa Szkolne i Pedagogiczne. 
Ragusa A. (2013). Rural Australian women legal help seeking for intimate partner violence: Women intimate partner violence victim survivors' perceptions of criminal justice support services. Journal of Interpersonal Violence, 28 (4), 685-717.

Rajska-Kulik I. (2007). Przemoc wewnątrzmałżeńska - uwarunkowania pozostawania maltretowanych kobiet w krzywdzącym związku. Chowanna, 1, 11-24.

Rao V. (1997). Wife-beating in rural South India: A qualitative and econometric analysis. Social Science and Medicine, 44, 1169-1180.

Shellie W., Lunn D. (2000). The Ontario Rural Woman Abuse Study. Ottawa: Department of Justice, Canada.

Szczepański J. (1971). Metoda biograficzna. In: J. Szczepański. Odmiany czasu teraźniejszego (pp. 573-607). Warsaw: Książka i Wiedza.

Szpak E. (2013). Mentalność ludności wiejskiej w PRL. Studium zmian. Warsaw: Wydawnictwo Naukowe Scholar.

Thomas W., Znaniecki F. (1976). Chłop polski w Europie i Ameryce. Vol. 1-5. Warsaw: Ludowa Spółdzielnia Wydawnicza.

Tryfan B. (1968). Pozycja społeczna kobiety wiejskiej. Warsaw: Książka i Wiedza.

Tryfan B. (oprac.) (1975). Czyste wody moich uczuć. Warsaw: Książka i Wiedza.

Tryfan B. (1987). Kwestia kobieca na wsi. Warsaw: Instytut Rozwoju Wsi i Rolnictwa PAN. Tryfan B. (1996). Ochrona socjalna rodziny wiejskiej. Warsaw: Instytut Rozwoju Wsi i Rolnictwa PAN.

United Nations. (1993). Declaration on the Elimination of Violence Against Women. Geneva: Office of the United Nations High Commissioner for Human Rights.

Wendt S. (2009a). Construction of local culture and impacts on domestic violence in an Australian rural community. Journal of Rural Studies, 25 (2), 175-184.

Wendt S. (2009b). Domestic Violence in Rural Australia. Annadale, NSW: Federation Press.

Wendt S. (2010). Building and sustaining local co-ordination: An Australian rural community responds to domestic and family violence. British Journal of Social Work, 40, 44-62.

Wendt S., Bryant L., Chung D., Elder A. (2015). Seeking help for domestic violence: Exploring rural women's coping experiences: State of the knowledge paper. Landscapes: State of the Knowledge, 4. Alexandria, NSW: Australia's National Research Organisation for Women's Safety.

Wendt S., Hornosty J. (2010). Understanding contexts of family violence in rural, farming communities: Implications for rural women's health. Rural Society, 20 (1), 51-63.

Wojtczak D. (2006). Postawy wobec kobiet wykorzystywanych seksualnie. Praca Socjalna, $1,27-46$.

World Health Organization. (2010). Preventing Intimate Partner and Sexual Violence against Women: Taking Action and Generating Evidence. Geneva.

World Health Organization. (2013). Global and regional estimates of violence against women: prevalence and health effects of intimate partner violence and non-partner sexual violence. Geneva.

http://apps.who.int/iris/bitstream/10665/85239/1/9789241564625_eng.pdf?ua=1 [accessed: 12.08.2016].

Znaniecki F. (1934). The Method of Sociology, New York: Ferrar Rinehart. 
Znaniecki F. (1938). Przedmowa. In: J. Chałasiński. Młode pokolenie chłopów: procesy i zagadnienia kształtowania się warstwy chłopskiej w Polsce (pp. X-XVIII). Vol. 1. Warsaw: Spółdzielnia Wydawnicza „Pomoc Oświatowa”.

Znaniecki F. (1988). Wstęp do socjologii. Warsaw: PWN.

Znaniecki F. (2009). Metoda socjologii, trans. E. Hałas. Warsaw: Wydawnictwo Naukowe PWN.

\section{Przemoc domowa wobec kobiet w społecznościach wiejskich}

Streszczenie: Przemoc domowa to trudny temat badawczy; zakłada się, że na jaw wychodzi tylko mała część zachowań przemocowych, ponieważ zarówno sprawcy, jak i ofiary przemocy mówią o niej niechętnie, ukrywają akty przemocy, boją się o niej opowiadać. Obecnie mówienie o przemocy i pomaganie jej ofiarom staje się jeszcze trudniejsze, gdyż przemoc domowa stała się tematem politycznym. Wskazują na to działania zmierzające do wypowiedzenia konwencji antyprzemocowej oraz odbieranie środków organizacjom niosącym pomoc ofiarom.

Mimo niepełnych danych statystyki wskazują, że skala problemu przemocy domowej jest duża. Niestety, o skali przemocy w społecznościach wiejskich wiemy jeszcze mniej niż o przemocy domowej w ogóle, choć badania światowe wskazują, że z różnych względów, analizowanych w artykule, może ona zachodzić na większą skalę i przybierać szczególne formy, jednak mała liczba badań empirycznych utrudnia pisanie o przemocy domowej na wsi. Celem prezentowanego artykułu jest omówienie definicji, próba oszacowania skali problemu przemocy domowej, prezentacja propozycji działań podejmowanych dla zapobiegania przemocy w społecznościach wiejskich w innych krajach, wreszcie analiza zjawiska przemocy w rodzinach wiejskich w Polsce na podstawie świadectw pochodzących $\mathrm{z}$ analizy pamiętników kobiet wiejskich.

Słowa kluczowe: przemoc domowa, przemoc wobec kobiet, kobiety wiejskie, pamiętniki. 